\title{
DLEC1 wt Allele
}

National Cancer Institute

\section{Source}

National Cancer Institute. DLEC1 wt Allele. NCI Thesaurus. Code C54432.

Human DLEC1 wild-type allele is located within 3p22-p21.3 and is approximately $261 \mathrm{~kb}$ in length. This allele, which encodes deleted in lung and esophageal cancer 1 protein, plays a role in tumor suppression. This allele is frequently deleted or abberantly expressed in several cancers. 